\title{
Possível relação dos polimorfismos no gene ABCB1 com as toxicidades induzidas por cisplatina em pacientes com câncer de cabeça e pescoço
}

\author{
Larissa B. Bastos*, Júlia C. F. Quintanilha, Maria A. Cursino, Marília B. Visacri, Camila O. Vaz, Nadine G. Torso, \\ Mário H. Hirata, Rosario D. R. C. Hirata, Carmem S. P. Lima, Patricia Moriel.
}

\section{Resumo}

O objetivo deste estudo é verificar possível relação dos polimorfismos do gene ABCB1 com as toxicidades induzidas por cisplatina em pacientes com câncer de cabeça e pescoço. Alem de caracterizar os pacientes quanto à mielotoxicidade, nefrotoxicidade, hepatotoxicidade e toxicidades gastrointestinais à cisplatina após primeiro ciclo de quimioterapia. Foram incluídos pacientes com câncer de cabeça e pescoço que realizaram tratamento antineoplásico com cisplatina (80-100 mg/m2 a cada 21 dias, por 3 ciclos; sendo considerado para a análise apenas o 1 ciclo) concomitante a radioterapia.

\section{Palavras-chave: \\ Cisplatina, polimorfismo, câncer cabeça e pescoço}

\section{Introdução}

O câncer de cabeça e pescoço corresponde aos tumores localizados no trato aerodigestivo superior. $\mathrm{O}$ tratamento mais efetivo consiste na radioterapia concomitante à quimioterapia com altas doses de cisplatina, entretanto, seu uso é limitado devido às suas reações adversas. $O$ ABCB1 é uma proteína transportadora de fármacos pertencente à família dos transportadores $A B C$, está envolvido no efluxo de cisplatina na célula estando, portanto, relacionado com a concentração intracelular do quimioterápico. Um polimorfismo no gene $A B C B 1$ pode interferir diretamente na eliminação da cisplatina na célula, alterando a concentração de cisplatina na mesma, e com isso podendo aumentar ou diminuir a toxicidade do medicamento. O objetivo deste estudo é verificar possível relação dos polimorfismos do gene ABCB1 com as toxicidades induzidas por cisplatina em pacientes com câncer de cabeça e pescoço. Foram incluídos pacientes com câncer de cabeça e pescoço que realizaram tratamento antineoplásico com cisplatina $(80-100 \mathrm{mg} / \mathrm{m} 2$ a cada 21 dias, por 3 ciclos; sendo considerado para a análise apenas o $1^{\circ}$ ciclo) concomitante a radioterapia.

\section{Resultados e Discussão}

Vinte e quatro parâmetros de toxicidades foram analisados para 50 pacientes. As características e dados clínicos dos pacientes estão apresentadas nas tabelas 1 e 2. Entre os parâmetros analisados para as toxicidades nós vimos uma variação significativa em leucócitos, linfócitos, bilirrubina total, creatinina, clearance de creatinina, sódio, ureia e ácido úrico, todos com $p<0,05$. Em relação aos polimorfismos nós observamos duas relações estatisticamente significantes do parâmetro sódio com o genótipo variante $A B C B 1$ rs1045642 e $A B C B 1$ rs2032582. Um polimorfismo no gene $A B C B 1$ pode interferir diretamente na eliminação da cisplatina na célula, alterando a concentração de cisplatina na mesma. Estes genes codificam a glicoproteína P (Pgp), e está localizado no rim, fígado e intestino, portanto, a atividade aumentada determinada pelo genótipo variante rs1045642 e rs2032582 deve estar relacionada ao nosso achado. Para o outro genótipo variante ABCB1 rs1128503 não foram encontrados valores significativos. Além disso, dos 50 pacientes incluídos no estudo, apenas 5 não foram obtidos os genótipos pois a amplificação não foi possível para o rs2031582.

Tabela 1. Genótipos dos polimorfismos rs1045642, rs1128503 e rs2031582 do gene da ABCB1 $(n=50)$.

\begin{tabular}{|l|c|c|c|c|}
\hline \multicolumn{5}{|c|}{ Polimorfismos da ABCB1 } \\
\hline & \multicolumn{4}{|c|}{ Número absoluto (Porcentagem) } \\
\hline & rs1045642 & rs1128503 & rs2031582 \\
\hline Homozigoto Selvagem & $20(40)$ & $22(44)$ & $34(68)$ & $35(70)$ \\
\hline Heterozigoto & $30(60)$ & $27(54)$ & $9(18)$ & $6(12)$ \\
\hline Homozigoto Variante & $0(0,0)$ & $0(0,0)$ & $5(10)$ & $6(12)$ \\
\hline Não amplificado & $0(0,0)$ & $0(0,0)$ & $2(4)$ & $3(6)$ \\
\hline
\end{tabular}

Tabela 2. Características dos pacientes e dados clínicos $(\mathrm{n}=50)$

\begin{tabular}{|l|c|}
\hline \multicolumn{2}{|c|}{ Paciente e características clínicas } \\
\hline $\begin{array}{l}\text { Idade (média } \pm \text { desvio padrão, } \\
\text { anos) }\end{array}$ & $58,32 \pm 7,93$ \\
\hline Sexo (n, \%) & \\
\hline Masculino & $46(92)$ \\
\hline Feminino & $4(8)$ \\
\hline KPS (n, \%) & $6(12)$ \\
\hline 100 & $36(72)$ \\
\hline 90 & $7(14)$ \\
\hline 80 & $1(2)$ \\
\hline 70 & \\
\hline Localização do tumor & $23(46)$ \\
\hline Orofaringe & $5(10)$ \\
\hline Hipofaringe & $10(20)$ \\
\hline Laringe & $12(24)$ \\
\hline Cavidade Oral & \\
\hline Estadio do tumor (n, \%) & $1(2)$ \\
\hline I & $4(8)$ \\
\hline II & $6(12)$ \\
\hline III & $39(78)$ \\
\hline IV & \\
\hline
\end{tabular}

\section{Conclusões}

Foi observado uma alta prevalência de toxicidades após a quimioterapia. Em relação aos polimorfismos estudados, acredita-se que com um $\mathrm{N}$ maior uma melhor correlação estatística poderá ser encontrada.

\section{Agradecimentos}

Ao CNPQ, CAPES e FAPESP pelo financiamento do projeto, à todos do laboratório CLIPHAR e à todos os pacientes que aceitaram participar da pesquisa. 